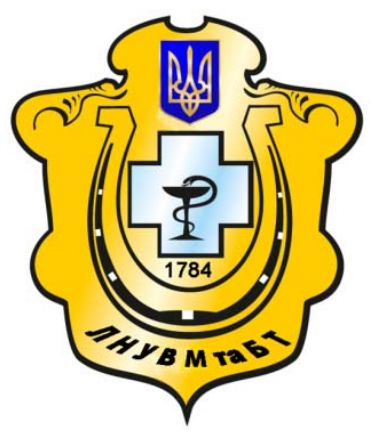

Науковий вісник Львівського національного університету ветеринарної медицини та біотехнологій імені С.3. Гжицького

Scientific Messenger of Lviv National University of Veterinary Medicine and Biotechnologies named after S.Z. Gzhytskyj

doi:10.15421/nvlvet7505

ISSN 2519-268X print

ISSN 2518-1327 online

$\underline{\text { http://nvlvet.com.ua/ }}$

УДК 637.1

\title{
Розроблення технології сиру «Моцарелла» із застосуванням різних молокозсідальних ферментів
}

\author{
О.Й. Цісарик, Л.Я. Мусій, І.М. Сливка, Т.Ф. Молокус \\ tsisaryk_o@yaoo.com, musiyluba@ukr.net, slyvka.88@ukr.net
}

Львівський національний університет ветеринарної медииини та біотехнологій імені С.3. Гжиџького, вул. Пекарська, 50, м. Львів, 79010, Украӥна

\begin{abstract}
Метою досліджень було розробити технологію м'якого сиру «Моцарелла» із використанням молокозсідальних ферментів різного походження та порівняти ефективність їх застосування. Молочну сировину для виробництва сиру заготовляли у березні 2016 р. Сир «Моцарелла» виготовляли з незбираного молока, яке аналізували на відповідність вимогам діючого Стандарту. Для сичужного зсідання молока використовували молокозсідальні ферменти різного походження: CHY-MAX Powder Extra NB верблюжсий фірми «Хр. Хансен Украӥна»-зразок 1; Меito мікробіальний фipми Меito Sangyo Сo (виробник Японія) - зразок 2; сичужний телячий фермент фірми ООО «Семенко» (Украӥна) - зразок 3. Тривалість сичужного зсідання молока визначали від моменту внесення ферментів у молочну основу до утворення щілльного згустку. У отриманих згустках визначали синеретичні властивості, вимірюючи об'єм виділеної сироватки через кожні 10 хв. протягом 1 год. У готовому продукті визначали вихід сиру та органолептичні показники. Встановлено, що при використанні верблюжого молокозсідального ферменту СНҮ-МАХ зменшується тривалість зсідання суміші, яка призводить до скорочення технологічного прочесу виробництва продукту. Зразок сиру, при використанні телячого сичужсного ферменту мав найвищі синеретичні властивості. 3 огляду на вихід готового сиру «Моцарелла» $з$ комериійною метою для отримання більшого прибутку, доиільно використовувати верблюжий фермент СНҮ-МАХ. Однак, зразок із використанням телячого сичужного ферменту, згідно органолептичної оцінки, характеризувався кращиии органолептичними показниками - вираженим сирним, властивим м'яким свіжим сирам смаком і запахом; пружною поверхнею; колір білий, рівномірний; ніжною, в міру щиільною консистенцією. Зразок при використанні мікробіального молокозсідального ферменту Меіто характеризувався найгіршими органолептичними показниками.

Ключові слова: м'який сир, Моцарелла, технологія, молокозсідальні ферменти, тривалість зсідання, синеретичні властивості, вихід сиру, органолептичні показники.
\end{abstract}

\section{Разработка технологии сыра «Моцарелла» с применением различных молокосвертывающих ферментов}

\author{
О.И. Цисарик, Л.Я. Мусий, И.Н. Сливка, Т.Ф. Молокус
}

tsisaryk_o@yaoo.com, musiyluba@ukr.net, slyvka.88@ukr.net

Львовский национальный университет ветеринарной медицины и биотехнологий имени С.3. Гљицкого, ул. Пекарская, 50, г. Львов, 79010, Украина

Целью исследований было разработать технологию мягкого сыра «Моцарелла» с использованием молокосвертывающих ферментов различного происхождения и сравнить эффективность их применения. Молочное сырье для производства сыра заготавливали в марте 2016 г. Сыр «Моиарелла» изготавливали из иельного молока, анализировали на соответствие требованиям действующего Стандарта. Для сычужного свертывания молока использовали молокосвертывающие ферменты различного происхождения: CHY-МАХ Powder Extra NB верблюжсий фирмы «Хр. Хансен Украина»-образеи 1; Меito микробиальный фирмы Meito Sangyo Со (Япония) - образеи 2; сычужный телячий фермент фирмы ООО «Семенко» (Украина) образеи 3. Продолжительность сычужного свертывания молока определяли с момента внесения ферментов в молочную

\section{Citation:}

Tsisaryk, O.I., Musiy, L.Ia., Slyvka, I.M., Molokus, T.F. (2017). The development of cheese technology «Mozzarella» with the usage of different curdle ferments. Scientific Messenger LNUVMBT named after S.Z. Gzhytskyj, 19(75), 23-28. 
основу до образования плотного сгустка. В полученных сгустках определяли синеретические свойства, измеряя объем выделенной сыворотки через каждые 10 мин. в течение 1 ч. В готовом продукте определяли выход сыра и органолептические показатели. Установлено, что при использовании верблюжьего молокосвертывающего фермента СНҮ-МАХ уменьшается продолжительность свертывания смеси, что приводит к сокращению технологического процесса производства продукта. Образец сыра с использованием телячьего сычужного фермента имел высокие синеретические свойства. Учитывая выход готового сыра «Моцарелла» ичелесообразно использовать верблюжий фермент СНҮ-МАХ. Однако, образеи с использованием телячьего сычужного фермента характеризовался, согласно органолептической оценки, лучиими органолептическими свойствами - выраженным сырным, свойственным мягким свежим сырам вкусом и запахом; упругой поверхностью; изетом бельм, равномерным; нежной, в меру плотной консистенцией. Образец с использованием микробиального молокосвертывающего фермента Меіто характеризовался худиими органолептическими показателями.

Ключевые слова: мягкий сыр, Моцарелла, технология, молокосвертывающье ферменты, продолжительность свертывания, синеретическые свойства, выход сыра, органолептические показатели.

\title{
The development of cheese technology «Mozzarella» with the usage of different curdle ferments
}

\author{
O.I. Tsisaryk, L.Ia. Musiy, I.M. Slyvka, T.F. Molokus \\ tsisaryk_o@yaoo.com,musiyluba@ukr.net, slyvka.88@ukr.net \\ Lviv National University of Veterinary Medicine and Biotechnologies named after S.Z. Gzhytskyi, \\ Pekarska Str. 50, Lviv, 79010, Ukraine
}

\begin{abstract}
The aim of the research was to develop the technology of soft cheese "Mozzarella» with the usage of curdle ferments of different origin and compare their efficiency and usage. Milk raw materials for cheese production was prepared in March $2016 r$. Cheese "Mozzarella» was produced from unskimmed milk which was analyzed according to the requirements of the current standard. For the process of rennet milk curdle one used curdle ferments of different origin: CHY-MAX Powder Extra NB camel of firm «Chr. Hansen Ukraine» - sample 1; Meito microbial of firm Meito Sangyo Co (producer in Japan) - sample 2; rennet calf ferment of firm OOO «Semenko» (Ukraine) - sample 3. The duration of rennet milk curdle was determined from the moment of ferment introduction into the milk mass till the creation of dense bunch. The synerethic peculiarities were determined in the obtained bunches, measuring the value of allocated whey every 10 minutes during 1 hour. The organoleptic indicators were determined in the finished product as well as the outcome of cheese. It is researched that while using camel milk curdle ferment CHY-MAX reduces the term of mixture curdle which lead to the shortening of the product manufacturing process. The sample of cheese, while using calf rennet ferment had the highest synerethic peculiarities. Taking into account the outcome of ready cheese product «Mozzarella» with the commercial aim to obtain better benefits, it is reasonably to use camel ferment CHY-MAX. However, the sample with the usage of calf rennet ferment, according to organoleptic evaluation, was characterized by better organoleptic peculiarities - marked cheese, peculiar for soft fresh cheese taste and scent; elastic surface; white color; soft, moderately dense texture. Sample, resulted from the usage of microbial milk curdle ferment Meito was characterized by the worst organoleptic indicators.
\end{abstract}

Key words: soft cheese, mozzarella, technology, curdle enzymes, coagulation duration, synerethic properties, cheese output, organoleptic properties.

\section{Вступ}

Серед молочних продуктів сир є одним із найкращих завдяки високій калорійності, фізіологічній повноцінності та різноманіттю смакових властивостей (Skrypnichenko, 2015). Харчова цінність сиру обумовлена високою концентрацією білка та жиру, високим вмістом вітамінів і солей кальцію, фосфору та магнію. Значна частина білків сиру знаходиться в легкодоступній для засвоєння формі організмом людини. Крім того, білки сиру містять усі незамінні амінокислоти в значній кількості (Shergina, 2009; Tkachenko and Skrypnichenko, 2016). Особливо популярним сьогодні $\epsilon$ м'які сири, які реалізують у свіжому вигляді (такі сири на споживному ринку України є альтернативою сирам кисломолочним), а також розсольні сири, які дешевші від твердих і напівтвердих сирів, тому користуються попитом серед споживачів. У групі розсольних сирів поширенішими на ринку України є Фета, Бринза і Моцарелла (Tkachenko and Skrypnichenko, 2016).

Сир Моцарелла відомий давно, вперше про нього згадується в книзі персонального кухаря Папи Римсь- кого Бартоломео Скіпрі. Промислове виробництво продукту налагодили в кінці XVIII століття (Mironenko and Usatjuk, 2015).

Перевагами виробництва м'яких сирів є: ефективне використання сировини; можливість реалізації сиру без визрівання або з коротким терміном визрівання (не більше 14 діб); добрі органолептичні показники; висока харчова та біологічна цінність; швидка оборотність капіталовкладень. На споживному ринку України сегмент м'яких сирів, в основному, представлений продуктами, які експортують з країн Свросоюзу (Gudkov, 2004; Kagan, 2009).

Центральною технологічною операцією при виробництві сирів є зсідання білків, тому одним із напрямів удосконалення традиційних технологій м'яких сирів $є$ підбір молокозсідальних ферментів. Молокозсідальні ферменти тваринного і рослинного походження відомі людству давно. Традиційно для отримання згустків 3 молока застосовували переважно натуральний молокозсідальний фермент - сичужний порошок, який отримували із шлунків ссавців. Дефіцит сичужного ферменту, що склався до середини 1970-х років у країнах розвиненого сироваріння Єв- 
ропи, Нової Зеландії, Австралії, США, Росії та ін., зумовив пошук нетрадиційних джерел сировини для виробництва молокозсідальних препаратів - замінників сичужного порошку - еталону для виробництва сирів. Сьогодні використовуються інші молокозсідальні ферменти, які близькі за дією до сичужного бактеріального чи грибкового походження (Pastuhov, 2010; Skrypnichenko and Tkachenko, 2014).

Для виробництва сиру придатні молокозсідальні ферменти, які здатні швидко розривати зв'язок між гідрофільною і гідрофобною частинами к-казеїну і не чинити негативного впливу на вихід і органолептичні властивості сирів. Молокозсідальні ферменти відрізняються між собою співвідношенням хімозину і пепсину та молокозсідальною активністю (Bannikova et al., 1987).

Метою нашої роботи було розробити технологію м'якого сиру «Моцарелла» із використанням молокозсідальних ферментів різного походження та порівняти ефективність їх застосування у його технології.

\section{Матеріал і методи досліджень}

Експериментальні дослідження розроблення технології м'якого сиру «Моцарелла» із використанням різних молокозсідальних ферментів проводились у лабораторії кафедри технології молока i молочних продуктів Львівського національного університету ветеринарної медицини та біотехнологій імені С.3. Гжицького. Молочну сировину для виробництва для виробництва сиру заготовляли у березні 2016 р. Сир «Моцарелла» виготовляли 3 незбираного молока, яке аналізували на відповідність вимогам діючого Стандарту «Молоко коров'яче незбиране. Вимоги при закупівлі» (ДСТУ 3662:1997).

Для сичужного зсідання молока використовували три молокозсідальні ферменти різного походження:

- CHY-MAX Powder Extra NB верблюжий фірми «Хр. Хансен Україна» у кількості 1 г на 100 л молока - зразок 1 ;

- Meito мікробіальний фірми Meito Sangyo Сo (виробник Японія) у кількості 1 г на 100 л молока - зразок 2 ;

- сичужний фермент телячий фірми ООО «Семенко» (Україна) у кількості 1 г на 100 л молока - зразок 3.

Зсідання білків здійснювали при температурі $32 \pm$ $1{ }^{\circ} \mathrm{C}$. Тривалість сичужного зсідання молока у хвилинах визначали від моменту внесення ферментів у молочну основу до утворення щільного згустку. У отриманих згустах визначали синеретичні властивості, вимірюючи об'єм виділеної сироватки через кожні 10 хв. протягом 1 год. У готовому продукті аналізували органолептичні показники та визначали вихід сиру.

\section{Результати та їх обговорення}

М'які сичужні сири виробляють 3 молока високого ступеня зрілості, кислотністю 22-24 ${ }^{\circ} \mathrm{T}$, за винятком свіжих сирів без дозрівання, для яких використовують молоко кислотністю до $20^{\circ} \mathrm{T}$.

Технологічна схема виробництва м'якого сиру «Моцарелла» при використанні молокозсідальних ферментів різного походження представлена на рисунку 1.

Основною сировиною для виробництва $є$ молоко коров'яче незбиране вищого і першого гатунків згідно ДСТУ 3662-97. Молоко пастеризують за температури $74 \pm 2{ }^{\circ} \mathrm{C}$. Охолоджене молоко поступає у ванни, де його нормалізують знежиреним молоком (м.ч.ж. $0,05 \%$ ) до масової частки жиру у нормалізованій суміші $3,1 \%$.

У охолоджену нормалізовану суміш вносять лимонну кислоту у вигляді $1,5 \%$ розчину у розрахунку 1,5 г на 1 л нормалізованої суміші. Перемішують суміш протягом 1 хв і підігрівають до температури $32 \pm$ $1{ }^{\circ} \mathrm{C}$. У підігріте молоко вносять молокозсідальні ферменти: CHY-MAX, Мeito і телячий ферменти у розрахунку 1 г на 100 л нормалізованої суміші. Молокозссідальні ферменти попередньо розчиняють у холодній дистильованій воді. Суміш перемішують 30 с і залишають у спокої для сичужного зсідання. Утворений сирний згусток розрізають на кубики розміром $2 \times 2$ см. Сирний згусток разом із сироваткою підігрівають до температури $43 \pm 1{ }^{\circ} \mathrm{C}$ для кращого іï відділення.

У подальшому відділяють сирний згусток від сироватки. Сироватку нагрівають до температури $85 \pm 1{ }^{\circ} \mathrm{C}$ і відірвавши шматочок від сирного згустку, занурюють його у гарячу сироватку на $5 \ldots 10$ с. Повторюють це кілька разів, формуючи еластичну сирну кульку. Частину сироватки охолоджують і використовують для зберігання м'якого сиру.

Зберігання сиру «Моцарелла» на підприємствахвиробниках, розподільчих холодильниках, у торговельній мережі, підприємствах громадського харчування, повинно проводитися відповідно до правил зберігання свіжих м'яких сирів на цих підприємствах, затверджених у встановленому порядку при відносній вологості повітря не більше $(80 \pm 5) \%$ (Shergina, 2009). Сирні кульки Моцарелли зберігають у охолодженій сироватці або розсолі. Термін придатності сиру «Моцарелла» за температури зберігання $4 \pm 2{ }^{\circ} \mathrm{C}$ не більше ніж 5 діб.

Застосування ферментів різного походження здійснюють вплив на тривалість зсідання молока. При цьому в'язкість суміші різко підвищується, що свідчить про зміни стану білків. Коагуляція відбувається у дві фази: ферментативну та видимої коагуляції, коли з'являються пластівці. Потім утворюється ніжний згусток, який у подальшому ущільнюється. Тривалість зсідання молока становить $30 \pm 5$ хв при температурі $30 \pm 2{ }^{\circ} \mathrm{C}$ (Diduh and Avershina, 2010).

На рисинку 2 наведено тривалість сичужного зсідання нормалізованої суміші при виробництві м'якого сиру «Моцарелла» iз використанням ферментів різного походження.

Тривалість зсідання нормалізованої суміші при виробництві сиру «Моцарелла» із використанням верблюжого ферменту скорочується на 4 хв. (14\%) порівняно 3 тривалістю зсідання суміші при використанні мікробіального ферменту і на 9 хв (26\%) порівняно 3 тривалість зсідання суміші при використанні телячого ферменту. 
3 огляду на зменшення тривалості зсідання суміші у зразку 1 , доцільно було б рекомендувати у виробництві м'якого сиру «Моцарелла» використовувати верблюжий молокозсідальний фермент, який призводить до скорочення технологічного процесу виробництва продукту.

Одним із показників якості готового сиру є масова частка вологи, яка залежить від синеретичних властивостей згустків.

На рисинку 3 представлені результати досліджень синеретичних властивостей сичужних згустків, отриманих зсіданням молока 3 використанням молокозсідальних ферментів CHY-MAX, Meito i телячого.

Синерезис - це процес відділення сироватки від згустку, що включає самовільне ущільнення структури за рахунок перегрупування частинок i збільшення числа контактів між ними, тобто ущільнення гелю та випресовування 3 нього дисперсійного середовища.

Дані проведених досліджень свідчать, що зразок 1, при зсіданні якого використовували верблюжий фермент CHY-MAX, має найнижчі синеретичні властивості порівняно 3 мікробіальним і телячим ферментами. Об'єм сироватки, що виділився за 1 год. для зразка 1 , становив $41 \%$, тоді як для зразків 2 і 3 47 і 56\% відповідно. Слід відзначити, що зразок 3 при використанні телячого сичужного ферменту мав найкращі синеретичні властивості. Отримані результати розширюють літературні дані щодо впливу молокозсідальних ферментів на синеретичні властивості згустків.

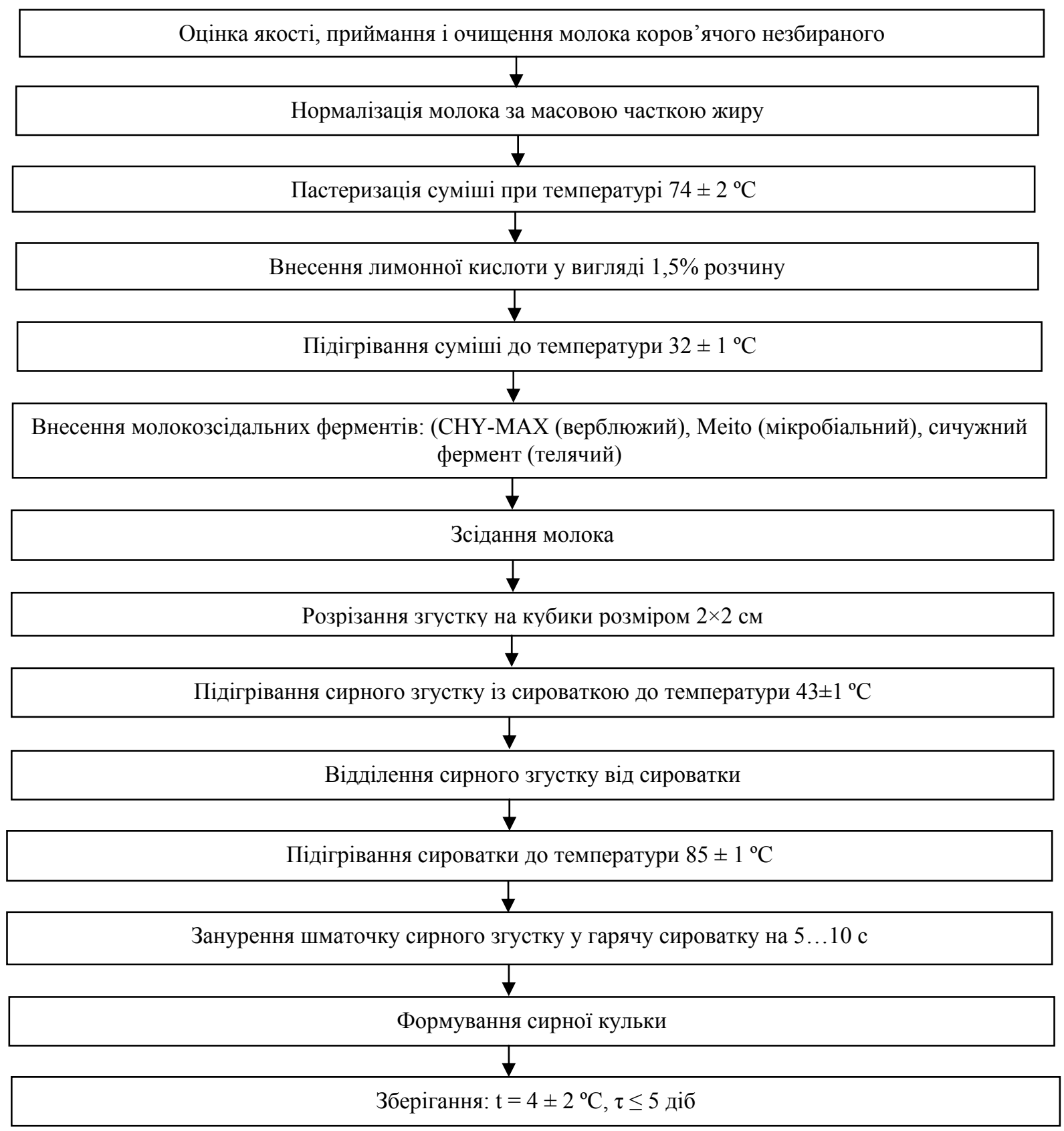

Рис. 1. Технологічна схема виробництва м'якого сиру «Моцарелла» із різними молокозсідальними ферментами 


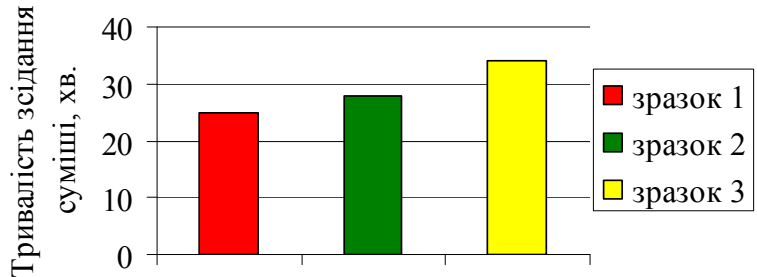

зразок 1 зразок 2 зразок 3 Зразки згустків

Рис 2. Тривалість зсідання нормалізованої суміші при виробництві м'якого сиру «Моцарелла» із використанням різних молокозсідальних ферментів

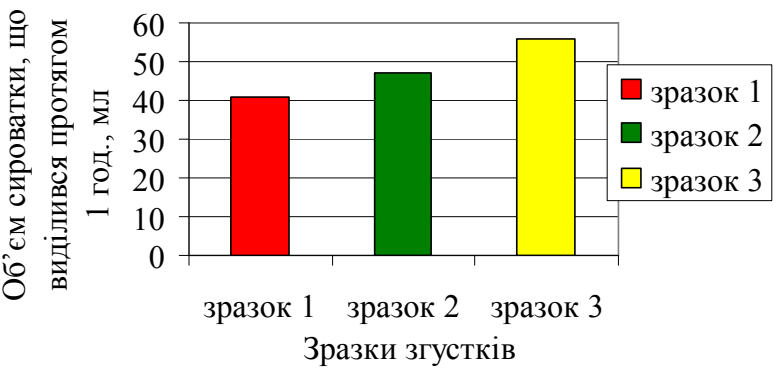

Рис. 3. Синеретичні властивості сичужних згустків, отриманих зсіданням молока 3 використанням молокозсідальних ферментів

3 огляду на синеретичні властивості згустків, для виробництва м'якого сиру «Моцарелла» перспективним $\epsilon$ використання телячого сичужного ферменту. Молокозсідальні ферменти та режими теплового оброблення молока суттєво впливають на вихід готового продукту. Наступним етапом досліджень було встановлення їх впливу на цей показник.

На рисинку 4 наведена залежність виходу готового продукту - м'якого сиру «Моцарелла» від виду молокозсідального ферменту. Як свідчать отримані дані, використання молозсідальних ферментів різного походження вплинуло на вихід м'якого сиру «Моцарелла». Зразок 3 при використанні телячого сичужного ферменту має нижчий вихід сиру, ніж зразки 1 і 2, що пояснюється утворенням більшої кількості казеїнового пилу, який переходить у сироватку. Найбільший вихід сиру відзначаємо при використанні верблюжого сичужного ферменту CHY-MAX фірми «Хр. Хансен Україна» (зразок 1).

Отже, з огляду на вихід готового сиру «Моцарелла» 3 комерційною метою для отримання більшого прибутку, доцільно використовувати верблюжий фермент СНY-MAX.

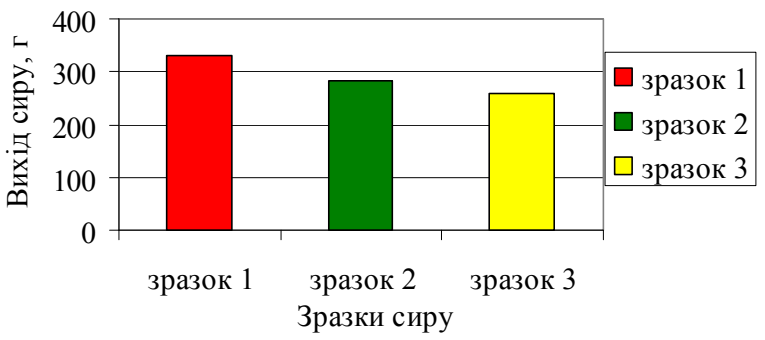

Рис. 4. Вихід готового продукту, отриманого зсіданням нормалізованої суміші з використанням молокозсідальних ферментів

Залежно від виду молокозсідально ферменту формуються органолептичні показники м'якого сиру «Моцарелла». Результати органолептичної оцінки наведені у таблиці 1. Згідно органолептичної оцінки зразок 3 із використанням телячого сичужного ферменту характеризувався вираженим сирним, кисломолочним, без сторонніх присмаків та запахів, властивий м'якому свіжому сиру смаком і запахом; поверхня чиста без механічних ушкоджень, пружна; консистенція мазка, ніжна, в міру щільна; колір білий, рівномірний за всією масою; тісто з наявністю вічок. Найгіршими органолептичними показниками характеризувався зразок 2 при використанні мікробіального молокозсідального ферменту Meito. Він характеризувався невираженим сирним смаком; зовнішній вигляд - колір білий $з$ кремовим відтінком; консистенція мазка, злегка крихка; тісто 3 наявністю невеликих пустот.

Таблиия 1

Органолептичні показники м'якого сиру «Моцарелла» із використанням різних молокозсідальних ферментів

\begin{tabular}{|c|c|c|c|}
\hline Показники & Зразок 1 & Зразок 2 & Зразок 3 \\
\hline $\begin{array}{l}\text { Зовнішній } \\
\text { вигляд }\end{array}$ & $\begin{array}{l}\text { Поверхня чиста без механі- } \\
\text { чних ушкоджень, жорстка }\end{array}$ & $\begin{array}{l}\text { Поверхня чиста без механічних } \\
\text { ушкоджень, в міру пружна }\end{array}$ & $\begin{array}{l}\text { Поверхня чиста без механічних } \\
\text { ушкоджень, пружна }\end{array}$ \\
\hline Смак і запах & $\begin{array}{l}\text { Сирний, кисломолочний, } \\
\text { без сторонніх присмаків та } \\
\text { запахів }\end{array}$ & $\begin{array}{l}\text { Невиражений сирний смак, без } \\
\text { сторонніх присмаків та запахів, } \\
3 \text { наявністю легкої кислуватості }\end{array}$ & $\begin{array}{l}\text { Сирний, кисломолочний, без } \\
\text { сторонніх присмаків та запахів, } \\
\text { властивий мякому свіжому сиру }\end{array}$ \\
\hline Консистенція & $\begin{array}{l}\text { Мазка, злегка ламка, в міру } \\
\text { щільна }\end{array}$ & $\begin{array}{l}\text { Мазка, злегка крихка, в міру } \\
\text { щільна }\end{array}$ & Мазка, ніжна, в міру щільна \\
\hline Колір тіста & $\begin{array}{l}\text { Білий з кремовим відтінком } \\
\text { рівномірний за всією ма- } \\
\text { сою }\end{array}$ & $\begin{array}{l}\text { Білий } з \text { кремовим відтінком } \\
\text { рівномірний за всією масою }\end{array}$ & $\begin{array}{l}\text { Білий рівномірний за всією ма- } \\
\text { сою }\end{array}$ \\
\hline Рисунок & $\begin{array}{l}\text { Тісто з вічками і наявністю } \\
\text { невеликих пустот }\end{array}$ & $\begin{array}{l}\text { Тісто з наявністю невеликих } \\
\text { пустот }\end{array}$ & Тісто з вічками \\
\hline Форма & Кулька & Кулька & Кулька \\
\hline
\end{tabular}




\section{Висновки}

Тривалість зсідання білків при виробництві сиру «Моцарелла» із використанням верблюжого ферменту становить 25 хв., при використанні мікробіального ферменту - 29 хв. і при використанні телячого ферменту -34 хв.

3 огляду на вихід готового сиру «Моцарелла» 3 комерційною метою для отримання більшого прибутку, доцільно використовувати верблюжий фермент CHY-MAX.

Згідно органолептичної оцінки зразок із використанням телячого сичужного ферменту характеризувався вираженим сирним, кисломолочним, без сторонніх присмаків та запахів, властивий м'якому свіжому сиру смаком і запахом; поверхня чиста без механічних ушкоджень, пружна; консистенція мазка, ніжна, в міру щільна; колір білий, рівномірний за всією масою; тісто з наявністю вічок. Найгіршими органолептичними показниками характеризувався зразок при використанні мікробіального молокозсідального ферменту Meito.

Перспективи подальших досліджень. В подальшому планується розроблення технології «Моцарелли» із застосуванням різних способів зсідання білків.

Робота виконана в рамках наукового проекту «Біотехнологія створення вітчизняних бактеріальних препаратів для молочної промисловості» (номер держреєстрації № 0116U208537).

\section{Бібліографічні посилання}

Skrypnichenko, D.M. (2015). Vyznachennja proteolitychnoi' aktyvnosti zakvashuval'nyh kompozycij dlja vyrobnyctva m'jakyh probiotychnyh syriv. Harchova nauka i tehnologija. 2, 34-38 (in Ukrainian).

Tkachenko, N.A., Skrypnichenko, D.M. (2016). Innovacijna tehnologija vyrobnyctva m'jakyh syriv z probiotychnymy

vlastyvostjamy. Wschodnioeuropejskie Czasopismo Naukowe (East European Scientific Journal). 6, 99-107 (in Ukrainian).

Shergina, I.A. (2009). Osobennosti proizvodstva mjagkih syrov. Pererabotka moloka. 2, 30-31 (in Russian).

Mironenko, I.M., Usatjuk, D.A. (2015). Mjagkie syry. Assortiment i tehnologicheskie osobennosti. Syrodelie i maslodelie. 4, 36-40 (in Russian).

Gudkov, A.V. (2004). Syrodelie: tehnologicheskie, biologicheskie i fiziko-himicheskie aspekty. M.: DeLi Print (in Russian).

Kagan, Ja.R. (2009). Syry s probioticheskoj mikrofloroj. Syrodelie i maslodelie. 2, 24-27 (in Russian).

Skrypnichenko, D.M., Tkachenko, N.A. (2014). Obg'runtuvannja racional'nogo vmistu molokozsidal'nogo fermentu CHY-MAX u vyrobnyctvi m'jakyh probiotychnyh syriv. Harchova nauka i tehnologija. 2(27), 24-29 (in Ukrainian).

Pastuhov, B.V. (2010). Molokosvjortyvajushhij fermentnyj preparat dlja mjagkih syrov. Pererabotka moloka. 8, 48 (in Russian).

Bannikova, L.A., Koroljova, N.S., Semenihina, V.F. (1987). Mikrobiologicheskie osnovy molochnogo proizvodstva: Spravochnik. M.: Agropromizdat (in Russian).

DSTU 3662-97 (1997). Moloko korov'jache nezbyrane. Vymogy pry zakupivli. Chynnyj vid 01.01.93. K.: Derzhstandart Ukrai'ny, 10 (in Ukrainian).

Diduh, N.A., Avershina, A.S. (2010). Vlijanie proteoliticheskih fermentov na razmer i srednjuju massu chastic kazeina $\mathrm{v}$ korov'em moloke. Novitni tehnologiï, obladnannja, bezpeka ta jakist' harchovih produktiv: s'ogodennja ta perspektivi: Materiali Mizhnarodnoï naukovo-prktichnoï konferenciï, 32 (in Ukrainian).

Стаття надійшла до редакції 15.03.2017 